Uyumaz, G., Mor-Dirlik, E., Çokluk, Ö. (2016). Açımlayıcı faktör analizinde tekrar edilebilirlik: kavram ve uygulama. Abant İzzet Baysal Üniversitesi Eğitim Fakültesi Dergisi, Cilt 16(2), 659675.

DOI:

\title{
AÇIMLAYICI FAKTÖR ANALIZINDE TEKRAR EDILEBILIRLIK: KAVRAM VE UYGULAMA
}

\author{
Gizem UYUMAZ* \\ Ezgi MOR DİRLIK*** \\ Ömay ÇOKLUK ${ }^{* * *}$
}

\section{ÖZET}

Temel araştırma niteliğindeki bu çalışmada, araştırmacılara açımlayıcı faktör analizinde tekrar edilebilirlik kavramının ve analizinin tanıtılması ve söz konusu analize yönelik bir örnek uygulamanın yapılması amaçlanmıştır. Kullanım sıklığıyla orantılı olarak, açımlayıcı faktör analizi, alanyazındaki tartı̧̧malı analizlerden biridir. Analiz, araştırmacıların inisiyatifleri doğrultusunda farklı şekillerde ilerledikleri birçok aşama içerdiğinden, aynı veri setiyle farklı araştırmacılar tarafından yapılan analizlerde kimi zaman farklı faktör yapılarının belirlenmesi dahi mümkün olabilmektedir. $\mathrm{Bu}$ durum da beraberinde sonuçların genellenebilirliği sorununu getirmektedir. Tekrar edilebilirlik analizi, hem bizzat ölçeği geliştiren araştırmacılar tarafindan, hem de sonrasında farklı araştırmacıların söz konusu ölçeği kullandıkları çalışmalarda elde edilebilecekleri ileri geçerlik kanıtlarından biridir. Bu sayede araştırmadan araştırmaya farklılık gösteren yapılar yerine, ölçeklere ilişkin daha güçlü ve tutarlı faktör yapıları ortaya koymak söz konusu olacaktır.

Anahtar Kelimeler: Açımlayııı Faktör Analizi, Tekrar Edilebilirlik, Ölçek Geliştirme

\section{THE REPLICATION ANALYSIS IN THE EXPLANATORY FACTOR ANALYSIS: CONCEPT AND APPLICATION}

\begin{abstract}
As a fundamental research, the presentation and acknowledgement of replicability concept in the explanatory factor analysis to researchers and to exemplify the usage of this analysis are aimed at in this study. Explanatory factor analysis has been used so frequently that it has become one of most discussed topics in the statistical field. This technique is composed of so many different stages that are determined by the researchers' initiatives; and due to this reason, sometimes different factor structures may be determined from the same data sets by the researchers. Determination of different factor structures makes the generalizability of the results a problematic issue. At this point, both the researchers developing a scale and the ones using a scale can resort to the replicability analysis in order to get advanced validity evidence. By using this analysis, instead of the flexible results that can be differ according to the research studies, stronger validity results can be obtained for the scale.
\end{abstract}

Key Words: Explanatory Factor Analysis, Replicability Analysis, Scale Development

\footnotetext{
* Akdeniz Üniversitesi, Ĕgitim Fakültesi, Eğitim Bilimleri Bölümü, Eğitimde Ölçme ve Değerlendirme Anabilim Dall,e-mail:gizemuyumaz@akdeniz.edu.tr

** Ankara Üniversitesi, Ĕgitim Bilimleri Fakültesi, Ölçme ve Değerlendirme Bölümü/ Ölçme ve Değerlendirme Anabilim Dall, e-mail:edirlik@ankara.edu.tr

*** Ankara Üniversitesi, Eğitim Bilimleri Fakültesi, Ölçme ve Değerlendirme Bölümü/ Ĕgitim Istatistiği ve Araştırma Anabilim Dalı, e-mail: cokluk@education.ankara.edu.tr
} 


\section{GİRIŞ}

Spearman tarafindan ilk olarak 1904 yılında tanıtılan faktör analizi, o tarihten itibaren psikolojide, eğitimde ve diğer bilim dallarında en çok kullanılan veri analizi tekniklerinden biri olmuştur (Thorndike, 1997). Birçok bilim dalında sıklıkla tercih edilen bu analiz ile ilgili çok sayıda kaynak ve çalışma bulunmakta, fakat bu yayınların çok azında analizin tarihçesine ilişkin bilgi verildiğine rastlanmaktadır. Aslında temelleri Pearson'ın (1901) çalışmalarına dayanan faktör analizi tekniğinin tarihi gelişimi incelendiğinde, bazı önemli görüşler göze çarpmaktadır. Bunlardan birinin Hotelling (1993) tarafından önerilen "temel bileşenler analizi”, diğerinin ise Thurston'un (1947) her değişkenin bir faktör altında olabildiğince yüksek, diğer faktörler altında ise olabildiğince düşük (sıfıra yakın) faktör yük değeri göstermesi şeklinde açıklanan "basit yapı" kriteri olduğu ifade edilebilir (Akt: Goodwin, 1999).

Faktör analizi, temel amacı veri matrisinin altında yatan yapıyı belirlemek ve tanımlamak olan çok değişkenli istatistiksel tekniklerin genel adıdır. Ölçek ya da anket maddelerine verilen yanıtlar gibi çok sayıda değişken arasındaki içsel ilişkilerin analiz edilmesiyle, faktör olarak adlandırılan ortak yapıların ortaya çıkarılmasını sağlayan bir analiz olan faktör analizi aracılığıyla veriler özetlenebilir ve değişkenler azaltılabilir (Hair, Anderson, Tatham ve Black, 1998). Kachigan (1986) faktör analizinin dört temel kullanımının: (1) Geniş bir değişken setinin altında yatan faktörleri belirlemek, (2) Değişken setini az sayıda faktörle ifade edilebilir hale getirmek, (3) Uygulamadaki problemlere çözüm üretmek amaciyla geniş bir değişken setinin temsilcisi olan az sayıdaki değişkeni belirlemek, (4) Nesneleri ya da bireyleri kendi aralarındaki ilişkilerini gözeterek homojen alt gruplara ayırmak olduğunu belirtmiştir.

Faktör analizi, sosyal bilimlerden fen bilimlerine kadar uzanan geniş bir alanda yapılan birçok araştırmada, açımlama ve doğrulama amaçlarına yönelik olarak kullanılabilir. Açımlayıcı faktör analizi (AFA), araştırmacının değişkenler arasındaki yapıyı ortaya çıkarmaya çalıştığı durumlar için uygunken, doğrulayıcı faktör analizi (DFA), söz konusu yap1 hakkında önceden belirlenmiş kuramlara ya da önceki araştırmalara dayalı hipotezlerin bulunduğu ve bunların test edilmesi ile ilgilenildiği durumlar için uygundur. AFA değişkenlerin olası kuramsal yapısını görmeyi sağlarken, DFA kuramsal yapının desteklenip desteklenmediğine ilişkin deneysel kanıt oluşturur (Goodwin, 1999). Ayrıca Raykov ve Marcoulides (2008) tarafından belirtildiği şekilde, AFA araştırmacıya ölçülen psikolojik yapı hakkında öngörü kazandıran ve çok sayıda değişkenin daha az sayıda faktörle özetlenmesini sağlayan bir analizdir. Bu tekniğin, en çok tercih edildiği durumlar psikolojik değişkenlerin ölçülmesi ve tanımlanmasıdır.

Açımlayıcı faktör analizi özellikle psikolojik ölçme aracı geliştirilirken sıklıkla tercih edilen güçlü ve yaygın kullanıma sahip bir teknik olsa da, AFA'ya ilişkin alanyazında tartışmalı birçok konu bulunmaktadır. Örneğin, hangi faktörleştirme yönteminin en doğru sonuçları verdiği, hangi durumlarda hangi döndürme tekniğinin uygun olduğu, faktör sayısına nasıl karar verileceği, üretilen faktörlerin nasıl yorumlanacağı, iyi bir faktör çözümlemesi için gereken örneklem büyüklüğü, sonuçların kuram test etmede kullanılıp kullanılmayacağı ve bu sonuçların ne derece genellenebileceği analize ilişsin uzun süredir devam eden tartışmalı konulardandır (Henson ve Roberts, 2006; Tabachnick ve Fidell, 2007). 
Açımlayıcı faktör analizi araştırmacılara verilerinin yapısını keşfetme olanağı sunmak üzere geliştirilen bir teknik olsa da, bu keşif süreci doğrulayıcı faktör analizinin çıkarımsal doğasından oldukça farklıdır (Osborne ve Fitzpatrick, 2012). Birçok araştırmacı AFA'nın yalnızca değişken seti arasındaki ilişkilerin ortaya çıkarılması durumunda kullanılması gerektiğini düşünürken, alanyazında ölçülen değişken setinin yapısına ilişkin ön bilgilerin olduğu durumlarda da AFA'nın kullanıldığ çalışmalar bulunmaktadır (Hair, Anderson, Tatham ve Black, 1998). Henson ve Roberts (2006) yaptıkları incelemede bu durumu gözlemlemiş ve özellikle sosyal bilimlerde yapılan çalışmaların üçte birinde AFA'nın doğrulayıcı nitelikte kullanıldığını tespit etmişlerdir. $\mathrm{Bu}$ durum kullanım yaygınlığına rağmen AFA'nın halen araştırmacılar tarafından anlaşılmayan yönleri olduğunu ortaya koymaktadır.

Söz konusu hatalı kullanımlarına rağmen, AFA değişkenler arasındaki tüm ilişkileri dikkate alarak çalışan bir analiz yöntemi olduğu için, diğer birçok analize göre daha fazla bilgi sunmakta ve değişkenler arasında betimlenen bu ilişkilerin evrendeki ilişkileri yansıtıp yansıtmadığı hakkında bilgi vermektedir. Bir diğer deyişle, çoklu regresyon kestirimlerinde olduğu gibi, AFA analiz edilen veriye olduğundan daha uyumlu model üretme eğilimi göstermekte ve aynı model yeni bir örnekleme uygulandığında, modelde nadiren iyi uyum sağlanmaktadır. Farklı örneklemlerle kullanıdığında genellikle benzer değerler elde edilemesine rağmen, çok farklı sonuçların ortaya çıktığı örnekler de mevcuttur. Dolayısıyla başka bir araştırmacı, söz konusu ölçme aracını kendi çalışmasındaki örnekleme uygulamadan önce geliştirilme çalışmasına benzer ya da bundan oldukça farklı sonuçlar elde edip edemeyeceğini bilememektedir. Bu nedenle özellikle ölçek geliştiren araştırmacıların, yapılan AFA'nın farklı örneklemlerde de benzer sonuçlar sağlayıp sağlamadığııı, bir başka deyişle belirlenen faktör yapısının tekrar edilebilirliğini inceleyip, yeni kullanıcılara ve araştırmacılara bu konuda bilgi vermesi gerekmektedir (Osborne ve Fitzpatrick, 2012).

\section{Açımlayıcı Faktör Analizinde Tekrar Edilebilirlik Neden Önemlidir ve Nasıl Belirlenir?}

Birçok araştırmacı AFA sonuçlarını doğrulayıcı bir dil kullanarak yorumlamakta ve elde edilen bulguları hipotez testi gibi kullanmaktadır. Fakat bu durum analizin adında da belirtilen açımlayıcı doğasına ters düşmekte, dolayısıyla elde edilen bulgularla ulaşılamayacak sonuçlara varılmaktadır. AFA'yı hipotez test etmek ya da önceden belirlenen fikirleri ve kuramları doğrulamak amacıyla kullanmak yerine, ölçeklerin doğasını anlamak ve maddeler arası korelasyonları incelemek amacıyla kullanmak gerekmektedir (Briggs ve Cheek, 1986; Floyd ve Widaman, 1995). Bir diğer deyişle AFA, doğasına ve amacına uygun olarak kullanılmalı ve mevcut ölçek yapısı hakkında bilgi toplamak analizin temel amacını oluşturmalıdır.

Açımlayıcı faktör analizi maddeler arasındaki ilişkileri kullanarak, yalnızca sunulan veri setine uygun faktörler üreten bir analizdir ve bu faktörlerin pratikte pek ortaya çıkmayan mükemmel koşullar (belirgin faktör yapısı, parametre başına düşen kişi sayısının çok yüksek olması, yüksek faktör yükleri ve ortak varyanslar gibi) dışında tekrar edilebilirliği oldukça düşüktür (Osborne ve Fitzpatrick, 2012). Birçok kestirisel istatistik tekniğinden elde edilen sonuçlar, analizin gerçekleştiği örneklemden farklı örneklemlere ne derece genellenebildiğine göre değişiklik göstermekte ve elde edilen bulgulara ilişkin güven aralıkları hesaplanmaktadır. Örneğin lojistik regresyon analizinde grup üyelikleri tahmin 
edilmekte ve oluşturulan modelin doğruluğu tahmin gücüyle ilişkili olarak değerlendirilmektedir. Ancak ne yazık ki AFA için böyle bir değerlendirme olanağı söz konusu değildir. Analizin genellenebilirliğine ya da elde edilen faktörlerin doğruluğuna ilişkin olarak kullanılabilecek bir ölçüt yoktur ve dolayısıyla araştırmacıların seçimine bağlı olarak farklı faktörlere ulaşılabilir. Buna ek olarak bir diğer problemin de, faktörleștirme işlemi tamamlandıktan sonra, hemen hemen aynı oranda varyans açılayan, fakat faktör yapısında küçük değişikliklere neden olan çok sayıda döndürme tekniğinin kullanılabilmesine ilişkindir (Tabachnick ve Fidell, 2007). Dolayısıyla daha önce de değinildiği üzere, AFA araştırmacının kendi inisiyatifini kullanarak ilerlediği bir çok aşama içerdiğinden, araştırmacıların farklı sonuçlara ulaşması da olası bir durumdur.

Araştırmacının kararlarıyla doğrudan ilişkili olan AFA sonuçlarının tekrar edilebilirliği ve elde edilen sonuçların güvenirliği, birçok faktörle doğrudan ilişkilidir. Analizin gücünü ve sonuçların kesinliğini etkileyen faktörlerden biri, veri setinin büyüklüğü (örneklem büyüklüğü)'dür. Kestirisel istatistiklerde genel olarak kabul gören örneklem büyüklüğü, her grup ya da değişken için minimum 10 katılımcıdır (Cohen ve Cohen, 1983). Ancak bu kural özellikle madde sayısının az olduğu ölçme araçları için geçerliğini yitirmektedir. Örneğin, Comrey ve Lee (1992) 300 kişilik örneklemi "iyi”, 500 kişilik örneklemi "çok iyi" ve 1000 kişilik örneklemi ise "mükemmel" olarak nitelendirmektedir. Ancak ölçekte 300 maddenin yer aldığı bir örnek durum için 300 kişilik bir örneklem büyüklüğünü halen "iyi” olarak nitelendirmek mümkün müdür? Buna benzer sorunlar nedeniyle farklı araştırmacılar tarafindan örneklem büyüklüğünün yeterliğine ilişkin farklı ölçütler önerilmiştir. Stevens (2002) ölçekte yer alan her bir madde başına 5 ile 20 arasında değişen katılımcı düşmesi gerektiğini belirtirken, Jöreskog ve Sörbom (1996) kestirilecek her parametre için en az 10 katılımcı olması gerektiğini ifade etmektedir. Sahip olunması gereken en az katılımcı sayısı, değişken sayısının 3 katı ile başlamakta ve 50 katına kadar varan geniş bir ranj tanımlanmaktadır (Goodwin, 1999).

Açımlayıcı faktör analizinin tekrar edilebilirliğini etkileyen tek faktör örneklem büyüklüğü değildir. Analizin farklı örneklemlerde benzer, tekrar edilebilir sonuçlar üretmesi kestirilen parametre sayısından da etkilenmektedir. 10 maddeden oluşan ve iki faktörlü bir yapı gösteren bir ölçek için özdeğerler ve ortak varyanslar hariç 20 parametre hesaplanırken, 20 maddeden oluşan ve üç faktörlü bir yapı gösteren bir ölçek için sadece faktör yükleri temel alındığında 60 parametre hesaplanmaktadır. Bu nedenle yüksek faktör yüklerine ve yüksek ortak varyansa sahip maddelerle, büyük örneklemlerle yapılacak AFA'nın gücü büyük oranda artacak, dolayısıyla buna bağlı olarak da tekrar edilebilirlik olasılı̆ğ yükselecektir (Osborne ve Fitzpatrick, 2012).

\section{Tekrar Edilebilirlik Analizlerinin Gerçekleştirilme Süreci}

Açımlayıcı faktör analizinin temel amacı, bir ölçme aracının özel bir çalışma grubu ya da örneklemdeki faktör yapısını keşfetmek olduğu için, elde edilen faktör yapısının ve sonuçların benzer veri setlerinde, farklı örneklemlerde elde edilip edilmeyeceği, bir diğer ifadeyle tekrar edilebilirliği sorgulanmalıdır (Osborne ve Fitzpatrick, 2012).

Faktör analizi için yapılan tekrar edilebilirlik analizleri Floyd ve Widaman (1995) tarafından "çapraz geçerlik çalışması" olarak adlandırılmış̧ır. İdeal olarak, örneklemin yeterince büyük olduğu durumlarda, katılımcılar seçkisiz olarak iki gruba ayrılarak her iki grupta da aynı faktör yapısının elde edilip edilemediği incelenir. Burada dikkat edilmesi gereken, grupların seçkisiz olarak ayrılmasıdır. Seçkisiz atama sayesinde 
grupların ölçülen özellik bakımından eşitliğinin sağlandığı varsayılır. Seçkisiz atamanın yapılamadığı durumlarda, örneğin kadınlar ve erkeklerin ayrı gruplara atandığı durumda, oluşturulan iki örneklem farklı özelliklere sahip olacağından dolayı, faktör yapısının değerlendirilmesi de zor olacaktır. Ölçülen değişkene ilişkin varyansın benzer olduğu gruplarda yapılan tekrar edilebilirlik analizlerinin benzer sonuçları vermemesi durumda ise, ölçülen psikolojik yapının gruplara göre değiştiği sonucuna ulaşılır. Bu durumda araştırmacı farklı gruplar için yeni ölçek geliştirme ya da her iki grupta da tutarlı olarak ölçme yapan maddeleri kullanma yollarından birini seçmelidir.

Açımlayıcı faktör analizinde tekrar edilebilirlik, "zayıf” ve "güçlü” tekrar edilebilirlik olmak üzere iki düzeyde incelenebilir. Tekrar edilebilirliğe ilişkin alt eşik, benzer bir örneklemde, benzer bir faktör yapısının ortaya çıkmasıdır. Farklı örneklemlerde aynı sayıda faktörün ortaya çıkması ve aynı maddelerin aynı faktörlere yüklenmesi beklenir. Bu durumda zayıf tekrar edilebilirlik sağlanmış olur. Daha güç bir tekrar edilebilirlik kanıtı ise, aynı faktörlere yüklenen aynı maddelerin faktör yükleri büyüklüklerinin de aynı ranjda değişmesidir. Bu durumda, söz konusu ölçme aracı için güçlü tekrar edilebilirliğin sağlandığı ifade edilebilir ve söz konusu ölçeğin farklı örneklemlerde kullanılması durumunda yapılan ölçme işlemine daha fazla güven duyulabilir. Dolayısıyla özellikle ölçek geliştirilenler tarafından belirlenen psikolojik yapının farklı örneklemlerde tekrar edilebilir olup olmadığg incelenmeli ve elde edilen bulgular ölçme aracı ile ilgili alanyazında yer almalıdır (Osborne ve Fitzpatrick, 2012).

Açımlayıcı faktör analizi için yapılacak tekrar edilebilirlik çalışmaları içsel ve dışsal tekrar edilebilirlik olmak üzere iki farklı şekilde gerçekleştirilebilir. İçsel tekrar edilebilirlik çalışmasında, araştırmacı varolan tek bir veri setini seçkisiz olarak iki ayrı örnekleme ayırıp her birine AFA uygularken, dışsal tekrar edilebilirlik analizinde ayrı ayrı toplanmış iki veri setine AFA uygulanır ve elde edilen bulgular karşılaştırılır. Temel faktör yapısının tekrar edilebilirliğinin belirlenmesi için gerek içsel, gerek dışsal tekrar edilebilirlik çalışmasında, araştırmacılar her örneklemde benzer işlemleri uygulamalı, aynı faktörleştirme ve döndürme yöntemini kullanılmalı ve aynı faktör sayısını tanımlamalıdır. Ardından her maddenin en yüksek faktör yükü verdiği faktör belirlenerek her analizde bu durumun benzer olup olmadığı incelenmelidir. Testte yer alan maddelerden biri bile bu örüntüyü bozarsa, bu ölçme aracı en temel tekrar edilebilirlik eşiği olan zayıf tekrar edilebilirliği bile karşılayamamış kabul edilir. Bu kurala uymayan maddeler az sayıda ise, analiz sonucunda bu maddelerin gözden geçirilmesi ya da ölçekten çıkarılması önerilebilir. Ancak tekrar edilebilirlik analizi sonucunda, çok sayıda madde bu yapıyı bozacak şekilde değişiklik gösteriyor ve aynı faktörlerde yer almıyorsa, bu durum araştırmacıya ölçeği kullanıma sunmadan önce köklü değişiklikler yapılması gerektiği yönünde önemli ipuçları sunar. Tekrar edilebilirlik çalışmaları genel olarak aşağıdaki adımlarla ilerler (Osborne ve Fitzpatrick, 2012):

1. Açımlayıcı faktör analizi, önceden belirlenen ve psikolojik yapıya uygun olan bir faktörleştirme ve döndürme yöntemi kullanılarak her örneklem için tekrarlanır.

2. Her madde için standardize edilmiş / döndürülmüş faktör yükleri hesaplanır. Örneklemler ve faktörler göz önünde bulundurularak her maddenin faktör yükünün listelendiği bir tablo oluşturulur.

3. Analizler sonucu elde edilen faktör yükleri ve ortaya çıkan faktör yapıları karşılaştırılır. 
Alanyazında bu karşılaştırmanın yapılmasında nelere dikkat edilmesi gerektiği ve hangi durumlarda tekrar edilebilirliğin düşük ya da yüksek olduğuna karar verilebileceğine ilişkin ayrıntılı bilgilere rastlanmamaktadır. Faktör yapılarının benzerliğini incelemek için hesaplanması önerilen farklı korelasyon katsayıları (örneğin Tucker'ın Uyuşum Katsayısı gibi) olmasına rağmen, bu katsayılar faktör yüklerinin büyüklüğünü inceleme dışı bırakmakta, yalnızca elde edilen örüntüyü dikkate almaktadır. Osborne ve Fitzpatrick (2012), söz konusu dezavantajın ortadan kaldırılmasına yönelik olarak, tekrar edilebilirliğin incelenmesinde adımsal bir yöntem önermişlerdir. Bu yönteme göre öncelikle maddelerin her analizde aynı faktör altında yer alıp almadığı incelenir. $\mathrm{Bu}$ incelemenin ardından her maddeye ilişkin hesaplanan faktör yüklerinin büyüklüklerinin yaklaşık olarak aynı olup olmadığına bakılır. Maddelerin yapılan her analizde aynı faktöre yüklenmesi tekrar edilebilirliğin en temel ve basit eşiğini (zayıf tekrar edilebilirliği) oluştururken, ikinci koşul olan faktör yüklerinin benzer büyüklükte (neredeyse eşit) olması, güçlü tekrar edilebilirliğin bir göstergesi olarak kabul edilmektedir. Faktör yüklerinin büyüklüklerini karşılaştırmak için, standardize edilmiş iki faktör yükü arasındaki fark hesaplanır ve bu farkın karesi alınır. Faktör yükleri arasındaki farkın karesinin alınmasının; önemsiz negatif ve pozitif değerleri yok etmek ve büyük farklılıkları daha net ortaya koymak gibi iki yararı vardır. Karesi alınan fark değerleri araştırmacılar tarafından gözden geçirilir ve böylece büyük ve küçük farkların daha kolay ayırt edilmesi sağlanır.

Açımlayıcı faktör analizi tekniği için yapılan tekrar edilebilirlik analizlerinin nasıl işlediği incelendiğinde, bunların genellikle çapraz geçerlik çalışmaları kapsamında yapıldığı görülmektedir. Bu konudaki ilk çalışmalardan biri Briggs ve Cheek (1986) tarafından Kendini Ayarlama Ölçeği'ne (Self Monitoring Scale) uygulanan tekrar edilebilirlik çalışmasıdır. Faktör analizinin kişilik ölçümlerinde kullanımının çeşitli yönlerden incelendiği bu çalışmada, ölçeğin faktör yapısının tekrar edilebilirliğe sahip olup olmadığı araştırılmıştır. Ayrıca bu ölçek kullanılarak yapılan daha önceki çalışmalarda uygulanan faktör analizi sonuçları da incelenmiş ve farklı örneklemlerden elde edilen AFA bulguları karşılaştırılmıştır. Çalışmada, özellikle kişilik gibi yapıların ölçülmesinde tekrar edilebilirlik analizlerinin önemine vurgu yapılmıştır.

Benzer bir başka çalışma ise Costa ve McRae (1997) tarafından yapılan ve beş faktörlü bir yapı sergileyen NEO Kişilik Envanteri'nin altı farklı dile çevrilmesi sonucunda elde edilen AFA bulgularının incelendiği çalışmadır. Bu çalışmada İngilizce, Almanca, Portekizce, İbranice, Çince, Korece ve Japonca'ya çevrilmiş ölçeğe tekrar edilebilirlik analizleri uygulanmış ve elde edilen sonuçlar, ölçeğin tüm dillerde güçlü tekrar edilebilirliği sağladığını ortaya koymuştur. Bu durum hem söz konusu ölçme aracının çevirilerinin yüksek nitelikli olduğunu, hem de beş faktör modelinin evrenselliğini ortaya çıkarmıştır (Akt: Osborne ve Fitzpatrick, 2012). Dolayısıyla AFA'nın tekrar edilebilirliğine ilişkin yapılan çalışmalar hem ölçme aracıyla yapılan ölçümlerin geçerliği ve güvenirliği hakkında daha fazla ve sağlam kanıtlar sunmakta, hem de ölçülen yapının farklı örneklemlerde test edilmesini sağlamaktadır.

Costello ve Osborne (2005) çok net ve güçlü faktör yapısına sahip olan Rosenberg ÖzBakış Envanteri'ni (Rosenberg Self-View Inventory) kullanarak, maddelerin doğru faktörler altında yer alıp almama durumunu ve maddelerin bu faktörlerdeki yüklerinin ne kadar değiştiğini incelemişlerdir. Eğitim ortamlarında toplanan gerçek verilerin değişen örneklem büyüklüklerinde yüzlerce simülasyonu yapılmış ve genel olarak AFA'nın 
oldukça tutarsız sonuçlar verdiği belirlenmiş̧tir. Madde başına 10 katılımcının düştüğü durumlarda, analizlerin \%60'ında beklenen faktör yapısının elde edildiği, madde başına 20 katılımcının düştüğü durumlarda ise analizlerin \%70'inde net ve güçlü bir faktör yapısının elde edilebildiği belirlenmiş̧tir. Rosenberg Öz-Bakış Envanteri faktör yapısı çok net ve faktör yükleri çok yüksek bir ölçme aracı olmasına karşın böylesine tutarsız sonuçların elde edilmesi, faktör yapısı daha karmaşık olan ya da daha düşük faktör yüklerine sahip olan ölçme araçlarından elde edilecek sonuçların tutarsız olma olasıllı̆ııı güçlendirmektedir.

AFA ile ilgili çalışmaların incelenmesinden elde edilen bir diğer bulgu da birçok çalışmada AFA uygulamasından elde edilen sonuçların, tekrar edilebilirlik göstergesi olan eşik değerlerin (zayıf tekrar edilebilirlik / aynı maddelerin aynı faktörlerde yer alması) altında kaldığını belirtmektedir (Osborne ve Fitzpatrick, 2012). Henson ve Roberts (2006), AFA yapılan çalışmaları inceledikleri araştırmalarında, incelenen makalelerde ele alınan örneklem büyüklüklerinin ortancasının 267, katılımc1/madde oranı ortalamasının 11 ve kestirilen parametre sayısı ortancasının 60 olduğunu belirlemişlerdir. Costello ve Osborne (2005) tarafından Henson ve Roberts'ın bulgularının genişletildiği bir başka simülasyon çalışmasında ise, incelenen AFA uygulamalarının $\% 60$ 'dan daha azında tekrar edilebilir basit ve açık faktör yapısı bulunduğu belirlenmiştir.

Osborne (2008) tarafından yapılan bir başka çalışmada ise, sosyal bilimlerde kullanılan AFA'ların çoğunda madde başına düşen katılımcı sayısının 10'dan az olduğu belirtilmiştir. Benzer şekilde, raporlanan çalışmalarının üçte ikisinin tekrar edilebilirliğinin sağlanamayacak düzeyde olduğu vurgulanmıştır. Thompson (1999) bu durumun bilimin en temel prensiplerinden biri olan "tekrar edilebilirlik" açısından son derece rahatsız edici olduğunu ifade etmiştir.

$\mathrm{Bu}$ çalışma kapsamında bu aşamaya kadar, AFA için tekrar edilebilirlik analizleri hakkında bilgi verilmiş (önemi, nasıl yapılması gerektiği, ölçme araçları için tekrar edilebilirliğin sağlanma ya da sağlanamama kararı vb.) ve alanyazında yer alan tekrar edilebilirlik analizi çalışmalarına değinilmiştir. Bu kısım çalışmanın tekrar edilebilirliğe ilişkin kavramsal tartışmalarını oluşturmaktadır. Bundan sonraki kısımda ise, bir veri seti üzerinde içsel tekrar edilebilirlik analizini örneklendirmek amaçlanmış ve elde edilen bulgular yorumlanmıştır.

\subsection{Araştırmanın Amacı}

$\mathrm{Bu}$ çalışmada öncelikle açımlayıcı faktör analizinde tekrar edilebilirlik kavramının açıklanması, ardından tekrar edilebilirlikle ilgili bir örnek uygulama gerçekleştirilmesi amaçlanmıştır.

\subsection{Araştırmanın Önemi}

Sosyal bilimlerde oldukça yaygın kullanımına karşın, hatalı örnekleri ile de sıklıkla karşılaşılan açımlayıcı faktör analizinde, en önemli tartışmalardan birini "sonuçların genellenebilirliği" sorunu oluşturmaktadır. Bu soruna çözüm oluşturabilecek önerilerden biri, ileri bir geçerlik kanıtı olan tekrar edilebilirlik analizidir. Araştırmacıların inisiyatifleri doğrultusunda yapılandırılan süreç sonucunda elde edilen farklı bulgular yerine, ölçeklere ilişkin daha güçlü ve geçerli faktör yapılarının elde edilebilmesi, hem 
ölçek geliştirme çalışmalarında hem de geliştirilen ölçeklerin kullanımı ile ilgili sonraki çalışmalarda tekrar edilebilirlik analizlerinin yapılmasını gerekli kılmaktadır. Bu çalışma ölçek geliştiren araştırmacılara AFA ile belirledikleri faktör yapısının tekrar edilebilirliğini nasıl inceleyecekleri konusunda hem kavramsal, hem de uygulamalı bilgi vermesi açısından oldukça önemlidir.

\section{YÖNTEM}

\subsection{Araştırma Modeli}

Çalışma kapsamında açımlayıcı faktör analizinde tekrar edilebilirlik analizi hakkında bilgi verilmesi ve söz konusu analize yönelik bir örnek uygulama yapılması amaçlandığından çalışma temel araştırma niteliğindedir.

\subsection{Veriler}

Bu çalışma kapsamında, faktör yapısı daha önceden belirlenmiş bir ölçek verisine ihtiyaç duyulduğundan, araştırmacıların bilgisi ve izinleri doğrultusunda, Deniz, Saatçioğlu ve Mor-Dirlik (2014) tarafından geliştirilmiş olan Mesleki Motivasyon Ölçeği'nin geliştirilme aşamasında toplanan veriler kullanılmıştır. Veriler, 2013-2014 öğretim yılı güz döneminde Ankara Üniversitesi Eğitim Bilimleri Fakültesinin farklı lisans programlarında ve farklı sınıf düzeylerinde öğrenim görmekte olan 469 öğrenciden elde edilmiştir.

\subsection{Mesleki Motivasyon Ölçeği}

Deniz, Saatçioğlu ve Mor-Dirlik (2014) tarafından Öz-Belirleme ve Çift Etmen Kuramı temel alınarak geliştirilen Mesleki Motivasyon Ölçeği, bireylerin kendi algılarına dayalı olarak mesleki motivasyon düzeylerinin belirlenmesini amaçlayan bir ölçektir. Ölçek kapsamında bireylerin mesleki motivasyon düzeylerini etkilediği belirtilen ve "hijyen faktörleri" olarak adlandırılan faktörlerden; "gelir”, "gelecek güvencesi”, "yükselme olanakları", "takdir", “çevre etkisi”, "çalışma şartları", "mesleki gelişim”, "maddi ödül”, "yönetici baskısı" ve "tanınma" olmak üzere 10 boyuta ilişkin maddeler yer almaktadır. Ölçek, "Hiç Uygun Değil”, "Uygun Değil”, "Kararsızım”, "Uygun” ve "Tamamen Uygun" şeklinde tepki kategorilerine sahip beşli Likert tipi yanıtlama skalasına uygun olarak düzenlenmiştir. Ölçekte yer alan 60 maddenin 50'si olumlu 10'u ise olumsuz ifadelerden oluşmaktadır. Ölçeğin geliştirilme aşamasında yapılan açımlayıcı ve doğrulayıcı faktör analizleri sonucunda, ölçeğin motivasyonsuzluk, içsel motivasyon ve dışsal motivasyon olmak üzere üç faktörlü bir yapıdan oluştuğu ve belirlenen üç faktörün toplam varyansın \%43'ünü açıkladığı belirlenmiştir. Ölçekteki 60 maddenin tamamının faktör yük değerleri 0.40 'ın üzerinde olduğundan, hiçbir maddenin çıkartılmasına ihtiyaç duyulmamıştır. Nihai formu 60 maddeden oluşan ölçek için hesaplanan Cronbach-alpha iç tutarlılık katsayılarının "Motivasyonsuzluk" boyutu için 0.94, "Dışsal Motivasyon" boyutu için 0.92 ve "İçsel Motivasyon" boyutu için ise 0.96 olduğu saptanmıştır. Bu değerler ölçek maddelerinin boyutlara göre yüksek iç tutarlılığa sahip olduğunu göstermektedir. 


\subsection{Verilerin Analizi}

Bu çalışmanın amacı doğrultusunda bir veri seti üzerinde açımlayıcı faktör analizinde içsel tekrar edilebilirlik analizi örneklendirilmeye çalışılmıştır. Söz konusu analiz bu çalışmanın kavramsal açıklamalarında da belirtildiği gibi, iki aşamada gerçekleştirilmiştir. Tekrar edilebilirlik analizine başlamadan önce, 469 kişiden oluşan tüm veri seti için açımlayıcı faktör analizi uygulaması yapılmış ve tekrar edilebilirlik analizinden elde edilen bulgularla karşılaşıırmalar yapılabilecek şekilde sonuçlar raporlanmıştır. Tekrar edilebilirlik analizi kapsamındaki ilk aşamada, veri seti seçkisiz olarak ikiye ayrılmış, ikinci aşama olarak ise her veri seti için ayrı ayrı açımlayıcı faktör analizi uygulaması yapılmış ve raporlanmıştır.

Açımlayıcı faktör analizlerine geçmeden önce hem 469 kişiden oluşan tüm veri seti, hem de bu veri setinin seçkisiz olarak ikiye ayrılmasından oluşan veri setleri AFA uygulamasına uygunluk açısından incelenmiştir. İlk olarak veri setindeki kayıp değerler incelenmiş, tüm veri setlerinde kayıp değerlerin \%5'in altında olduğu ve herhangi bir örüntü sergilemediği belirlenmiştir. Kayıp değerlerin yerine değer atama işlemleri tam veri setiyle yüksek benzerlik gösteren yöntemlerden biri olduğundan (Şahin-Kürşad ve Nartgün, 2015) yakın noktaların medyanı (4) kullanılarak gerçekleştirilmiştir. Kayıp değer atama işleminin ardından uç değer incelemeleri yapılmış ve veri setlerinde uç değer bulunmadığı belirlenmiştir. Açımlayıcı faktör analizinin çoklu bağlantılılık, çok değişkenli normallik ve doğrusallık incelemeleri de yapılarak veri setleri açımlayıcı faktör analizine hazır hale getirilmiştir (Çokluk, Şekercioğlu ve Büyüköztürk, 2014).

Veri setlerine açımlayıcı faktör analizi uygulamasında faktörleştirme yöntemi olarak temel bileşenler analizi kullanılmıştır. Değişkenler arasındaki ilişkiler korelasyon matrisi temel alınarak incelenmiştir. Döndürme yöntemi olarak da varimax dik döndürme yöntemi kullanılmıştır. Hem faktörleştirme, hem de döndürme yönteminin belirlenmesinde, ölçeğin geliştirilme çalışmasındaki (Deniz, Saatçioğlu ve Mor-Dirlik, 2014) seçimlere bağlı kalınmıştır.

\section{BULGULAR}

Çalışmanın bu bölümünde sırasıyla üç farklı veri setine ilişkin betimsel istatistikler ve bu veri setlerine uygulanan açımlayıcı faktör analizleri bulguları karşılaştırmalı olarak sunulmuştur.

Çalışma kapsamında kullanılan üç farklı veri setine ilişskin betimsel istatistikler Tablo 1'de yer almaktadır. Tablo 1'de "tüm grup" olarak ifade edilen veri seti, 469 kişilik orijinal veri setidir. Veri-1 ve Veri-2 olarak adlandırılan veri setleri ise, orjinal veri setinin seçkisiz olarak ikiye ayrılmasından elde edilen (sırasıyla 235 ve 234 kişilik) veri setleridir. 
Tablo 1.

Veri Setlerine İlişkin Betimsel İstatistikler

\begin{tabular}{lrrr}
\hline & Tüm Grup & Veri-1 & Veri-2 \\
\hline N & 469.00 & 235.00 & 234.00 \\
Ortalama & 218.20 & 219.97 & 216.33 \\
Medyan & 221.00 & 222.00 & 218.00 \\
Mod & 208.00 & 226.00 & 208.00 \\
Standart Sapma & 33.52 & 34.34 & 31.99 \\
Varyans & 1123.32 & 1178.95 & 1023.58 \\
Çarpıklık & -1.01 & -1.27 & -0.70 \\
Çarpıklığın Standart Hatası & 0.11 & 0.16 & 0.16 \\
Basıklık & 2.55 & 3.76 & 1.03 \\
Basıklığın Standart Hatası & 0.23 & 0.32 & 0.32 \\
Ranj & 236.00 & 231.00 & 191.50 \\
En Küçük Değer & 63.00 & 67.00 & 87.50 \\
En Büyük Değer & 299.00 & 298.00 & 279.00 \\
\hline
\end{tabular}

Tablo 1'de sunulan, veri setlerine ilişkin betimsel istatistikler incelendiğinde ortalama, medyan ve moddan oluşan merkezi eğilim ölçülerinin tüm veri setlerinde birbirine yakın olduğu, dolayısıyla grupların motivasyon düzeylerinin benzer olduğu sonucuna ulaşılabilir. Standart sapma ve varyans gibi dağılım ölçülerinin de merkezi eğilim ölçüleri gibi birbirine yakın olduğu görülmektedir. Veri setlerine ilişkin betimsel istatistiklerin benzer değerler alması, gruplar arasında büyük farklılıklar olmadığı, dolayısıyla her veri setinden elde edilecek faktör yapılarının da benzer olacağı beklentisini ortaya çıkarmaktadır. Tekrar edilebilirlik analizlerinde, analizin yapılacağı grupların çok farklılaşmaması istenen bir durumdur; aksi takdirde faktör yapılarındaki değişikliklerin kaynağını yorumlamanın da güçleşeceği vurgulanmaktadır (Osborne ve Fitzpatrick, 2012). Bu çalışma için söz konusu benzerlik durumunun sağlandığı belirtilebilir.

Çalışmadaki farklı veri setlerinin örneklem büyüklüklerinin açımlayıcı faktör analizi için uygunluğu Kaiser Mayer Olkin (KMO) değerleri incelenerek belirlenmiştir. Çok değişkenli normalliğin göstergesi olarak kabul edilen Bartlett Küresellik Testi de aynı şekilde, her veri seti için incelenmiş ve sonuçlar Tablo 2'de sunulmuştur.

Tablo 2.

Veri Setlerine İlişkin KMO Değerleri ve Bartlett Küresellik Testi Sonuçları

\begin{tabular}{llrrr}
\hline & & Tüm Grup & Veri-1 & Veri-2 \\
\hline \multirow{2}{*}{ KMO } & & 0.926 & 0.890 & 0.888 \\
\hline & Ki-kare & 20427.67 & 10969.35 & 10653.50 \\
& sd & 1770 & 1770 & 1711 \\
& $\mathrm{P}$ & 0.000 & 0.000 & 0.000 \\
\hline
\end{tabular}

Tablo 2 incelendiğinde, veri setlerinin örneklem büyüklüklerinin yeterliğine ilişkin bilgi veren KMO değerlerinin tüm veri setlerinde 0.90 civarında olduğu görülmektedir. $\mathrm{Bu}$ sonuçlar "mükemmel" (Tabachnick ve Fidell, 2007) olarak nitelendirilebilir ve veri setlerinin açımlayıcı faktör analizi yapmak için yeterli büyüklüklere sahip olduğu anlamında yorumlanabilir. Verilerin çok değişkenli normal dağılıma uygunluğunu test eden Bartlett Küresellik Testi ise bir ki-kare $\left(\chi^{2}\right)$ istatistiğidir ve bu test sonucu elde edilen manidarlık düzeyi 0.05 'in altındaysa, veri setine ilişkin korelasyon matrisinin birim matristen farklı olduğu sonucuna ulaşılır (Tabachnick ve Fidell, 2007). Oluşturulan 
tüm veri setleri için hesaplanan Bartlett Küresellik Testi sonuçlarının 0.05 'ten küçük olduğu belirlenmiş ve dolayısıyla veri setlerinin açımlayıcı faktör analizi uygulamak için gerekli şartı karşıladığı sonucuna ulaşılmıştır.

KMO ve Barlett Küresellik Testi sonuçlarının incelenmesinin ardından, faktör sayısına karar vermede oldukça yaygın bir kullanıma sahip olan yamaç-birikinti grafikleri yine tüm veri setleri için incelenmiş ve Şekil 1'de sunulmuştur.
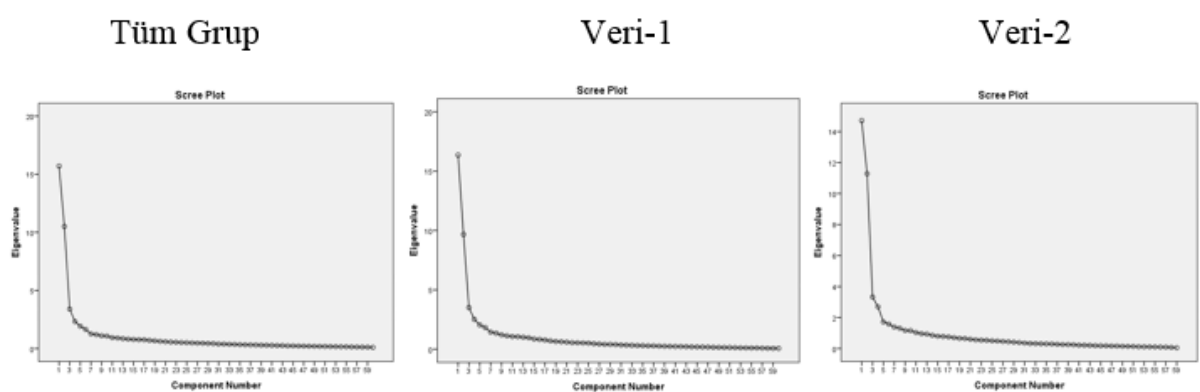

Şekil 1. Veri Setlerine İlişkin Yamaç-Birikinti Grafikleri

Şekil 1 incelendiğinde, tüm veri setleri için üç faktörlü yapının uygun olduğu görülmektedir. $\mathrm{Bu}$ nedenle açımlayıcı faktör analizleri üç faktörlü yapı üzerinden gerçekleştirilmiş̧tir.

Yapılan açımlayıcı faktör analizleri sonucunda elde edilen standartlaştırılmış (döndürülmüş) faktör yük değerleri ve tekrar edilebilirlik analizi yapılan iki veri setine (Veri-1 ve Veri-2) ilişkin maddelerin en yüksek faktör yükü verdiği faktörlerdeki standardize edilmiş faktör yükleri farklarının kareleri (SEFYFK) Tablo 3'te verilmiştir.

\begin{tabular}{|c|c|c|c|c|c|c|c|c|c|c|c|c|}
\hline \multirow{2}{*}{\multicolumn{4}{|c|}{$\begin{array}{c}\text { Orijinal Faktör Yapısı } \\
\text { Tüm Grup }\end{array}$}} & \multicolumn{8}{|c|}{ Tekrar Edilebilirlik Analizi } & \multirow{3}{*}{$\frac{\text { SEFYFK }}{(\text { V1-V2) }}$} \\
\hline & & & & \multicolumn{4}{|c|}{ Veri-1 } & \multicolumn{4}{|c|}{ Veri-2 } & \\
\hline & F1 & $\mathrm{F} 2$ & F3 & & F1 & F2 & F3 & & F1 & $\mathrm{F} 2$ & F3 & \\
\hline M5 & 0.710 & -0.036 & 0.266 & M5 & 0.732 & 0.009 & 0.275 & M5 & 0.676 & -0.072 & 0.280 & 0.003 \\
\hline M6 & 0.675 & -0.072 & 0.218 & M6 & 0.663 & -0.117 & 0.235 & M6 & 0.681 & -0.010 & 0.218 & \\
\hline M11 & 0.754 & -0.047 & 0.157 & M11 & 0.776 & -0.049 & 0.194 & M11 & 0.725 & -0.057 & 0.147 & 0.003 \\
\hline M12 & 0.756 & -0.087 & 0.077 & M12 & 0.724 & -0.101 & 0.120 & M12 & 0.777 & -0.062 & & \\
\hline M17 & 0.694 & -0.053 & 0.253 & M17 & 0.654 & -0.043 & 0.324 & M17 & 0.727 & -0.063 & 0.208 & 005 \\
\hline M18 & 0.735 & -0.042 & 0.169 & M18 & 0.684 & -0.078 & 0.228 & M18 & 0.777 & -0.001 & 0. & 0.009 \\
\hline M23 & 0.719 & -0.021 & 0.276 & M23 & 0.774 & -0.005 & 0.240 & M23 & 0.665 & -0.028 & & \\
\hline M24 & 0.716 & -0.077 & 0.204 & M24 & 0.721 & -0.057 & 0.209 & M24 & 0.718 & -0.067 & 0.1 & 0.000 \\
\hline M29 & 0.694 & 0.023 & 0.251 & M29 & 0.716 & 0.075 & 0.300 & M29 & 0.694 & -0.009 & 0.1 & \\
\hline M30 & 0.731 & 0.016 & 0.251 & M30 & 0.747 & 0.085 & 0.205 & M30 & 0.716 & -0.005 & 0.302 & 0.001 \\
\hline M35 & 0.734 & 0.034 & 0.162 & M35 & 0.746 & 0.089 & 0.146 & M35 & 0.734 & 0.005 & 0.163 & \\
\hline M36 & 0.745 & -0.010 & 0.112 & M36 & 0.792 & 0.068 & 0.111 & M36 & 0.706 & -0.064 & 0.119 & \\
\hline M41 & 0.690 & 0.063 & 0.211 & M41 & 0.691 & 0.130 & 0.199 & M41 & 0.690 & -0.007 & 0.232 & 0.000 \\
\hline M42 & 0.684 & 0.059 & 0.074 & M42 & 0.717 & 0.095 & 0.038 & M42 & 0.643 & 0.019 & 0.134 & 05 \\
\hline M47 & 0.676 & 0.122 & & M47 & 0.682 & & & M47 & 0.680 & & & 000 \\
\hline M48 & 0.757 & -0.009 & 0.158 & M48 & 0.741 & -0.003 & 0.125 & M48 & 0.780 & 0.021 & 0.189 & 0.002 \\
\hline M53 & 0.691 & 0.083 & 0.043 & M53 & 0.640 & 0.121 & 0.045 & M53 & 0.745 & 0.063 & 0.027 & \\
\hline M54 & 0.677 & 0.032 & -0.028 & M54 & 0.666 & 0.057 & -0.058 & M54 & 0.693 & 0.028 & -0.001 & 0.001 \\
\hline M59 & 0.656 & 0.115 & 0.311 & M59 & 0.664 & 0.166 & 0.342 & M59 & 0.660 & 0.101 & 0.260 & 0.000 \\
\hline M60 & 0.681 & 0.048 & 0.292 & M60 & 0.713 & 0.078 & 0.327 & M60 & 0.646 & 0.042 & 0.262 & 0.004 \\
\hline M2 & -0.180 & 0.580 & 0.039 & M2 & -0.134 & 0.621 & 0.095 & M2 & -0.242 & 0.518 & -0.037 & 0.011 \\
\hline
\end{tabular}


Gizem UYUMAZ, Ezgi MOR DİRLIK, Ömay ÇOKLUK

\begin{tabular}{|c|c|c|c|c|c|c|c|c|c|c|c|c|}
\hline & ijinal Fa & ktör Ya & ipısı & & & & krar Ed & lilebili & lik Ana & & & \\
\hline & Tüm & Grup & & & & ri-1 & & & & & & SEFYFK \\
\hline & F1 & F2 & F3 & & F1 & F2 & F3 & & F1 & F2 & F3 & $(\mathrm{V} 1-\mathrm{V} 2)^{2}$ \\
\hline M3 & -0.149 & 0.367 & -0.138 & M3 & -0.010 & 0.367 & -0.121 & M3 & -0.295 & 0.344 & -0.155 & 0.001 \\
\hline M4 & -0.169 & 0.514 & 0.024 & M4 & -0.044 & 0.563 & 0.021 & M4 & -0.293 & 0.453 & 0.010 & 0.012 \\
\hline M8 & -0.155 & 0.649 & 0.137 & M8 & -0.130 & 0.685 & 0.108 & M8 & -0.205 & 0.605 & 0.174 & 006 \\
\hline M9 & -0.032 & 0.615 & 0.290 & M9 & -0.001 & 0.646 & 0.284 & M9 & -0.073 & 0.583 & 0.285 & 0.004 \\
\hline M10 & -0.035 & 0.668 & 0.212 & M10 & 0.014 & 0.688 & 0.227 & M10 & -0.104 & 0.644 & 0.211 & 0.002 \\
\hline M14 & -0.069 & 0.608 & 0.129 & M14 & -0.016 & 0.598 & 0.163 & M14 & -0.130 & 0.622 & 0.070 & 0.001 \\
\hline M15 & 0.148 & 0.544 & 0.251 & M15 & 0.138 & 0.537 & 0.254 & M15 & 0.160 & 0.561 & 0.250 & .001 \\
\hline M16 & 0.189 & 0.566 & 0.193 & M16 & 0.236 & 0.537 & 0.215 & M16 & 0.138 & 0.598 & 0.170 & 0.004 \\
\hline M20 & -0.006 & 0.704 & -0.043 & M20 & 0.010 & 0.662 & -0.024 & M20 & -0.034 & 0.739 & -0.065 & 0.006 \\
\hline M21 & 0.154 & 0.638 & 0.051 & M21 & 0.123 & 0.587 & 0.106 & M21 & 0.164 & 0.675 & 0.012 & 008 \\
\hline M22 & 0.099 & 0.663 & 0.103 & M22 & 0.088 & 0.626 & 0.192 & M22 & 0.090 & 0.690 & 0.029 & 004 \\
\hline M26 & 0.034 & 0.566 & -0.274 & M26 & 0.014 & 0.592 & -0.231 & M26 & 0.039 & 0.529 & -0.316 & 0.004 \\
\hline M27 & 0.111 & 0.614 & -0.217 & M27 & 0.138 & 0.640 & -0.141 & M27 & 0.068 & 0.576 & -0.291 & 0.004 \\
\hline M28 & 0.092 & 0.578 & -0.094 & M28 & 0.075 & 0.574 & 0.010 & M28 & 0.086 & 0.564 & -0.195 & 000 \\
\hline M32 & -0.112 & 0.695 & 0.155 & M32 & -0.119 & 0.680 & 0.203 & M32 & -0.125 & 0.701 & 0.113 & 0.000 \\
\hline M33 & 0.122 & 0.600 & 0.345 & M33 & 0.129 & 0.555 & 0.403 & M33 & 0.102 & 0.651 & 0.281 & 0.009 \\
\hline M34 & 0.115 & 0.606 & 0.346 & M34 & 0.141 & 0.542 & 0.455 & M34 & 0.076 & 0.663 & 0.243 & 0.015 \\
\hline M38 & 0.081 & 0.574 & 0.206 & M38 & 0.182 & 0.510 & 0.274 & M38 & -0.047 & 0.646 & 0.159 & 0.018 \\
\hline M39 & 0.350 & 0.455 & 0.349 & M39 & 0.365 & 0.465 & 0.409 & M39 & 0.324 & 0.454 & 0.294 & 0.000 \\
\hline M40 & 0.377 & 0.443 & 0.354 & M40 & 0.399 & 0.411 & 0.378 & M40 & 0.366 & 0.485 & 0.308 & .005 \\
\hline M44 & -0.143 & 0.696 & 0.043 & M44 & -0.138 & 0.686 & 0.104 & M44 & -0.161 & 0.695 & -0.019 & 0.000 \\
\hline M45 & -0.007 & 0.718 & 0.069 & M45 & -0.018 & 0.675 & 0.116 & M45 & -0.009 & 0.751 & 0.009 & 0.006 \\
\hline M46 & 0.009 & 0.693 & 0.125 & M46 & 0.022 & 0.649 & 0.160 & M46 & -0.010 & 0.733 & 0.080 & 0.007 \\
\hline M50 & 0.050 & 0.535 & 0.333 & M50 & 0.037 & 0.493 & 0.365 & M50 & 0.038 & 0.602 & 0.343 & 0.012 \\
\hline M51 & 0.223 & 0.467 & 0.441 & M51 & 0.202 & 0.367 & 0.509 & M51 & 0.225 & 0.576 & 0.396 & 0.044 \\
\hline M52 & 0.238 & 0.464 & 0.428 & M52 & 0.254 & 0.347 & 0.505 & M52 & 0.218 & 0.572 & 0.354 & 0.051 \\
\hline M56 & -0.069 & 0.744 & -0.080 & M56 & -0.074 & 0.786 & -0.072 & M56 & -0.078 & 0.690 & -0.090 & 0.009 \\
\hline M57 & 0.058 & 0.747 & -0.034 & M57 & 0.085 & 0.785 & -0.044 & M57 & 0.024 & 0.706 & -0.035 & 0.006 \\
\hline M58 & 0.065 & 0.753 & -0.047 & M58 & 0.080 & 0.746 & -0.018 & M58 & 0.038 & 0.759 & -0.074 & 0.000 \\
\hline M1 & 0.245 & 0.135 & 0.553 & M1 & 0.263 & 0.131 & 0.530 & M1 & 0.144 & 0.217 & 0.595 & 0.004 \\
\hline M7 & 0.290 & 0.099 & 0.644 & M7 & 0.324 & 0.106 & 0.619 & M7 & 0.086 & 0.252 & 0.693 & 0.005 \\
\hline M13 & 0.243 & 0.049 & 0.692 & M13 & 0.197 & 0.085 & 0.679 & M13 & 0.026 & 0.277 & 0.722 & 0.002 \\
\hline M19 & 0.263 & 0.078 & 0.684 & M19 & 0.206 & 0.044 & 0.753 & M19 & 0.119 & 0.322 & 0.622 & 0.017 \\
\hline M25 & 0.279 & 0.012 & $\mathbf{0 . 6 4 5}$ & M25 & 0.226 & -0.013 & 0.644 & M25 & 0.035 & 0.342 & 0.651 & 0.000 \\
\hline M31 & 0.284 & 0.084 & 0.706 & M31 & 0.314 & 0.100 & 0.740 & M31 & 0.066 & 0.268 & 0.673 & 0.004 \\
\hline M37 & 0.286 & 0.090 & 0.708 & M37 & 0.264 & 0.146 & 0.747 & M37 & 0.042 & 0.327 & 0.650 & 0.009 \\
\hline M43 & 0.167 & 0.078 & 0.698 & M43 & 0.119 & 0.066 & 0.703 & M43 & 0.096 & 0.220 & 0.683 & 0.000 \\
\hline M49 & 0.234 & 0.079 & 0.724 & M49 & 0.149 & 0.084 & 0.731 & M49 & 0.084 & 0.329 & 0.699 & 0.001 \\
\hline M55 & 0.264 & 0.151 & 0.663 & M55 & -0.234 & 0.054 & 0.056 & M55 & 0.146 & 0.272 & 0.655 & 0.359 \\
\hline
\end{tabular}

Tablo 3 incelendiğinde, her üç veri seti için de aynı maddelerin aynı faktörlerde en yüksek yükü verdiği görülmektedir. Bu durum ölçeğin faktör yapısının zayıf tekrar edilebilirlik koşulunu sağladığı anlamına gelmektedir. Daha önce belirtildiği üzere, bir veri seti için güçlü tekrar edilebilirlik analizlerinin yapılabilmesi için, öncelikle zayıf tekrar edilebilirlik koşulunun sağlanması gerekir.

Ölçeğin zayıf tekrar edilebilirliği sağlamasının ardından, maddelerin faktör yük değerlerinin benzer olmasını gerektiren güçlü tekrar edilebilirliği sağlayıp sağlamadığı incelenmiştir. $\mathrm{Bu}$ amaçla farklı veri setlerinden hesaplanan maddelere ilişkin faktör yüklerinin en yüksek faktör yük değeri verdiği faktördeki standardize edilmiş faktör yükü ile diğer veri setinden hesaplanan standardize edilmiş faktör yükü arasındaki farklar hesaplanmıştır. Söz konusu fark değerlerinin daha nesnel bir şekilde karşılaştırılmasını 
sağlamak için fark değerlerinin kareleri alınarak sonuçlar negatif değerlerden arındırılmıştır. Hesaplanan değerler incelendiğinde, maddelerin en yüksek faktör yükü verdikleri faktördeki faktör yükleri büyüklüklerinin, farklı veri setlerinde yaklaşık olarak eşit olduğu, farklı veri setlerinden hesaplanan faktör yükü farklarının karelerinin de Osborne ve Fitzpatrick (2012) tarafından kritik değer olarak belirtilen 0.4'den küçük olduğu görülmektedir. Fark değerlerinin sözü edilen kritik değeri aşmaması, bu farkların ihmal edilebilirliği (önemsiz olduğu) anlamına gelmekte ve dolayısıyla ölçeğin güçlü tekrar edilebilirlik koşulunu da sağladığı görülmektedir. Ancak 55 numaralı madde için faktör yükleri farkının karesi kritik değere oldukça yakındır ve Veri-2 için faktör yük değeri çok düşüktür. Bu madde incelenmelidir.

Sonuç olarak bu çalışmada kullanılan ölçeğin üç faktörlü yapısının farkı veri setlerinde aynı şekilde elde edilmiş olması, ölçeğin geçerliğine ilişkin ek bir kanıt oluşturmaktadır.

Bu çalışmanın tekrar edilebilirlik çalışmalarına bir örnek oluşturması amaçlandığından, faktör yapısının yanlış tanımlandığı durumlarda ortaya çıkacak sonuçların ortaya konulması amacıyla, ölçek üç faktörlü yapı yerine iki faktörlü yapıya zorlanmış ve açımlayıcı faktör analizleri her veri seti için iki faktörlü yapı üzerinden tekrarlanmıştır.

$\mathrm{Bu}$ yanlış tanımlamanın ölçeğin zayıf ve güçlü tekrar edilebilirliğine zarar vermesi, dolayısıyla bu anlamda geçerlik kanıtlarının elde edilememesi beklenmektedir. Her bir veri seti için iki faktörlü yapı temel alınarak yapılan açımlayıcı faktör analizleri sonucunda elde edilen standartlaştırılmış faktör yük değerleri ve tekrar edilebilirlik analizi yapılan iki veri setine (Veri-1 ve Veri-2) ilişkin maddelerin en yüksek faktör yükü verdiği faktörlerdeki standardize edilmiş faktör yükleri ile diğer veri setindeki faktör yüklerinin farklarının kareleri (SEFYFK) Tablo 4'te sunulmuştur.

Tablo 4. İki Faktörlü Yapı için Veri Setlerine İlişkin Standartlaştırılmış Faktör Yük Değerleri ve Standardize Edilmiș Faktör Yükleri Farklarının Kareleri

\begin{tabular}{|c|c|c|c|c|c|c|c|c|c|}
\hline \multirow{2}{*}{\multicolumn{3}{|c|}{$\begin{array}{c}\text { Orijinal Faktör Yapısı } \\
\text { Tüm Grup }\end{array}$}} & \multicolumn{6}{|c|}{ Tekrar Edilebilirlik Analizi } & \multirow{3}{*}{$\frac{\text { SEFYFK }}{(\mathrm{V} 1-\mathrm{V} 2)^{2}}$} \\
\hline & & & & \multicolumn{2}{|c|}{ Veri-1 } & & \multicolumn{2}{|c|}{ Veri-2 } & \\
\hline & F1 & $\mathrm{F} 2$ & & F1 & F2 & & F1 & $\mathrm{F} 2$ & \\
\hline M1 & 0.486 & 0.215 & M1 & 0.481 & 0.224 & M1 & 0.485 & 0.214 & 0.000 \\
\hline M5 & 0.749 & -0.055 & M5 & 0.774 & -0.003 & M5 & 0.725 & -0.093 & 0.002 \\
\hline M6 & 0.695 & -0.097 & M6 & 0.697 & -0.127 & M6 & 0.699 & -0.043 & 0.000 \\
\hline M7 & 0.570 & 0.193 & M7 & 0.577 & 0.215 & M7 & 0.564 & 0.170 & 0.000 \\
\hline M11 & 0.733 & -0.092 & M11 & 0.776 & -0.083 & M11 & 0.702 & -0.105 & 0.005 \\
\hline M12 & 0.696 & -0.147 & M12 & 0.696 & -0.144 & M12 & 0.701 & -0.130 & 0.000 \\
\hline M13 & 0.553 & 0.158 & M13 & 0.494 & 0.222 & M13 & 0.598 & 0.113 & 0.011 \\
\hline M17 & 0.729 & -0.073 & M17 & 0.730 & -0.034 & M17 & 0.734 & -0.101 & 0.000 \\
\hline M18 & 0.722 & -0.082 & M18 & 0.712 & -0.093 & M18 & 0.742 & -0.057 & 0.001 \\
\hline M19 & 0.567 & 0.183 & M19 & 0.538 & 0.199 & M19 & 0.589 & 0.184 & 0.003 \\
\hline M23 & 0.761 & -0.040 & M23 & 0.795 & -0.029 & M23 & 0.735 & -0.043 & 0.004 \\
\hline M24 & 0.724 & -0.108 & M24 & 0.735 & -0.081 & M24 & 0.719 & -0.107 & 0.000 \\
\hline M25 & 0.562 & 0.110 & M25 & 0.505 & 0.116 & M25 & 0.619 & 0.104 & 0.013 \\
\hline M29 & 0.727 & 0.000 & M29 & 0.771 & 0.069 & M29 & 0.695 & -0.048 & 0.006 \\
\hline M30 & 0.759 & -0.009 & M30 & 0.752 & 0.053 & M30 & 0.772 & -0.028 & 0.000 \\
\hline M31 & 0.596 & 0.191 & M31 & 0.626 & 0.239 & M31 & 0.567 & 0.145 & 0.003 \\
\hline M35 & 0.717 & -0.010 & M35 & 0.724 & 0.043 & M35 & 0.718 & -0.042 & 0.000 \\
\hline M36 & 0.703 & -0.064 & M36 & 0.748 & 0.009 & M36 & 0.671 & -0.114 & 0.006 \\
\hline M37 & 0.599 & 0.197 & M37 & 0.584 & 0.290 & M37 & 0.606 & 0.112 & 0.000 \\
\hline M41 & 0.704 & 0.032 & M41 & 0.699 & 0.101 & M41 & 0.714 & -0.039 & 0.000 \\
\hline M42 & 0.630 & 0.002 & M42 & 0.647 & 0.026 & M42 & 0.625 & -0.024 & 0.000 \\
\hline M43 & 0.490 & 0.195 & M43 & 0.438 & 0.218 & M43 & 0.531 & 0.181 & 0.009 \\
\hline M47 & 0.682 & 0.089 & M47 & 0.684 & 0.147 & M47 & 0.691 & 0.028 & 0.000 \\
\hline M48 & 0.736 & -0.055 & M48 & 0.711 & -0.050 & M48 & 0.771 & -0.027 & 0.004 \\
\hline
\end{tabular}


Gizem UYUMAZ, Ezgi MOR DİRLIK, Ömay ÇOKLUK

Tablo 4. İki Faktörlü Yapı için Veri Setlerine İlişkin Standartlaştırılmış Faktör Yük Değerleri ve Standardize Edilmiş Faktör Yükleri Farklarının Kareleri

\begin{tabular}{|c|c|c|c|c|c|c|c|c|c|}
\hline \multirow{2}{*}{\multicolumn{3}{|c|}{$\begin{array}{c}\text { Orijinal Faktör Yapısı } \\
\text { Tüm Grup }\end{array}$}} & \multicolumn{6}{|c|}{ Tekrar Edilebilirlik Analizi } & \multirow{3}{*}{$\frac{\text { SEFYFK }}{(\mathrm{V} 1-\mathrm{V} 2)^{2}}$} \\
\hline & & & \multicolumn{3}{|c|}{ Veri-1 } & & \multicolumn{2}{|c|}{ Veri-2 } & \\
\hline & F1 & $\mathrm{F} 2$ & & F1 & $\mathrm{F} 2$ & & F1 & $\mathrm{F} 2$ & \\
\hline M49 & 0.561 & 0.195 & M49 & 0.477 & 0.238 & M49 & 0.632 & 0.161 & 0.024 \\
\hline M53 & 0.621 & 0.019 & M53 & 0.582 & 0.060 & M53 & 0.661 & -0.008 & 0.006 \\
\hline M54 & 0.574 & -0.044 & M54 & 0.557 & -0.028 & M54 & 0.602 & -0.042 & 0.002 \\
\hline M59 & 0.723 & 0.106 & M59 & 0.743 & 0.172 & M59 & 0.703 & 0.074 & 0.002 \\
\hline M60 & 0.735 & 0.034 & M60 & 0.781 & 0.078 & M60 & 0.692 & 0.019 & 0.008 \\
\hline M40 & 0.499 & 0.463 & M40 & 0.522 & 0.445 & M40 & 0.475 & 0.489 & 0.002 \\
\hline M55 & 0.556 & 0.251 & M55 & -0.181 & 0.092 & M55 & 0.561 & 0.221 & 0.551 \\
\hline M52 & 0.415 & 0.512 & M52 & 0.456 & 0.428 & M52 & 0.370 & 0.597 & 0.029 \\
\hline M2 & -0.142 & 0.592 & M2 & -0.087 & 0.636 & M2 & -0.225 & 0.527 & 0.012 \\
\hline M3 & -0.201 & 0.346 & M3 & -0.074 & 0.327 & M3 & -0.330 & 0.343 & 0.000 \\
\hline M4 & -0.139 & 0.523 & M4 & -0.041 & 0.554 & M4 & -0.246 & 0.475 & 0.006 \\
\hline M8 & -0.073 & 0.676 & M8 & -0.077 & 0.700 & M8 & -0.087 & 0.642 & 0.003 \\
\hline M9 & 0.110 & 0.660 & M9 & 0.120 & 0.691 & M9 & 0.082 & 0.626 & 0.004 \\
\hline M10 & 0.068 & 0.696 & M10 & 0.106 & 0.717 & M10 & 0.020 & 0.676 & 0.002 \\
\hline M14 & -0.001 & 0.625 & M14 & 0.051 & 0.618 & M14 & -0.073 & 0.635 & 0.000 \\
\hline M15 & 0.248 & 0.564 & M15 & 0.230 & 0.564 & M15 & 0.267 & 0.575 & 0.000 \\
\hline M16 & 0.255 & 0.571 & M16 & 0.299 & 0.545 & M16 & 0.209 & 0.601 & 0.003 \\
\hline M20 & -0.033 & 0.679 & M20 & -0.017 & 0.633 & M20 & -0.056 & 0.719 & 0.007 \\
\hline M21 & 0.154 & 0.616 & M21 & 0.146 & 0.579 & M21 & 0.154 & 0.648 & 0.005 \\
\hline M22 & 0.131 & 0.657 & M22 & 0.155 & 0.641 & M22 & 0.098 & 0.673 & 0.001 \\
\hline M26 & -0.111 & 0.495 & M26 & -0.110 & 0.515 & M26 & -0.118 & 0.465 & 0.003 \\
\hline M27 & -0.016 & 0.545 & M27 & 0.041 & 0.571 & M27 & -0.081 & 0.513 & 0.003 \\
\hline M28 & 0.028 & 0.536 & M28 & 0.058 & 0.549 & M28 & -0.017 & 0.514 & 0.001 \\
\hline M32 & -0.026 & 0.720 & M32 & -0.022 & 0.717 & M32 & -0.047 & 0.719 & 0.000 \\
\hline M33 & 0.272 & 0.640 & M33 & 0.293 & 0.618 & M33 & 0.233 & 0.674 & 0.003 \\
\hline M34 & 0.266 & 0.647 & M34 & 0.328 & 0.617 & M34 & 0.192 & 0.682 & 0.004 \\
\hline M38 & 0.167 & 0.592 & M38 & 0.279 & 0.539 & M38 & 0.043 & 0.664 & 0.016 \\
\hline M39 & 0.473 & 0.476 & M39 & 0.505 & 0.508 & M39 & 0.431 & 0.460 & 0.002 \\
\hline M44 & -0.109 & 0.702 & M44 & -0.087 & 0.702 & M44 & -0.144 & 0.695 & 0.000 \\
\hline M45 & 0.021 & 0.715 & M45 & 0.025 & 0.681 & M45 & 0.003 & 0.740 & 0.003 \\
\hline M46 & 0.064 & 0.700 & M46 & 0.081 & 0.663 & M46 & 0.037 & 0.733 & 0.005 \\
\hline M50 & 0.204 & 0.581 & M50 & 0.195 & 0.559 & M50 & 0.208 & 0.642 & 0.007 \\
\hline M51 & 0.408 & 0.519 & M51 & 0.412 & 0.454 & M51 & 0.396 & 0.606 & 0.023 \\
\hline M56 & -0.107 & 0.717 & M56 & -0.116 & 0.750 & M56 & -0.107 & 0.671 & 0.006 \\
\hline M57 & 0.027 & 0.716 & M57 & 0.037 & 0.739 & M57 & 0.009 & 0.686 & 0.003 \\
\hline M58 & 0.026 & 0.719 & M58 & 0.046 & 0.708 & M58 & 0.002 & 0.730 & 0.000 \\
\hline
\end{tabular}

Tablo 4 incelendiğinde, 40, 55 ve 52 nolu maddelerin farklı veri setlerinde, farklı faktörlerde en yüksek yük değeri verdiği görülmektedir. Örneğin madde 40, Tüm Grup olarak adlandırılan orjinal veri setinde ve Veri-1'de en yüksek faktör yük değerini birinci faktör altında verirken, Veri-2'de ise ikinci faktör altında vermekte ve bu faktöre yüklenmektedir. Madde 55, Tüm Grup ve Veri-2'de en yüksek faktör yük değerini birinci faktör altında verirken, Veri-1'de ise ikinci faktör altında vermekte ve bu faktöre yüklenmektedir. Madde 52 ise Tüm Grup ve Veri-2'de ikinci faktöre yüklenirken, Veri1 'de birinci faktöre yüklenmektedir. Bu bulgular ölçeğin iki faktörlü olarak tanımlandığı durumda, zayıf tekrar edilebilirlik koşulunu sağlamadığını ortaya koymaktadır. Ölçek orjinalde üç faktörlü bir yapıya sahip olduğundan, faktör yapısı farklılaştırıldığında tekrar edilebilirlik koşulu da bozulmuştur. Bu durum doğru tanımlamanın da önemini ortaya koymaktadır. Bir veri seti için güçlü tekrar edilebilirlik analizlerinin yapılabilmesi, öncelikle zayıf tekrar edilebilirlik koşulunun sağlanmasını gerekli kıldığından, ölçeğin güçlü tekrar edilebilirlik koşulunu sağlamayacağı sonucuna da doğrudan varılabilir. Yine de bunun bir kanıtı olarak Tablo 4'te yer alan ilgili maddelerin farklı veri setlerinde 
hesaplanan faktör yükleri farklarının karesi incelenebilir. Madde 55 için bu değerin 0.5 'den yüksek olması, Osborne ve Fitzpatrick (2012) tarafindan kritik değer olarak belirtilen 0.4 'ü aşmakta ve dolayısıyla ihmal edilebilir sınırın ötesine geçmektedir.

\section{TARTIŞMA ve SONUÇ}

Açımlayıcı faktör analizi, özellikle psikolojik ölçme aracı geliştirilirken, değişkenler arasındaki tüm ilişkileri hesaba katarak verinin yapısını keşfetmek, değişkenler arasındaki olası kuramsal yapıyı ortaya çıkarmak ve çok sayıda değişkeni daha az sayıda faktörle özetlemek amacıyla çok sık kullanılan güçlü bir tekniktir (Goodwin, 1999; Raykov ve Marcoulides, 2008). Her ne kadar sosyal bilimlerin bir çok alanında sıklıkla tercih edilen bir analiz olsa da, yanlış kullanımlara ve yorumlamalara açık olan bu analizden elde edilen sonuçların hem genellenebilirliğini, hem de elde edilen faktörlerin doğruluğunu değerlendirmede kullanılabilecek bellirli ölçütler geliştirilememiştir. $\mathrm{Bu}$ nedenle de elde edilen sonuçlar araştırmacıların analiz sürecindeki seçimlerine bağlı olarak değişmekte ve farklı araştırmacılar tarafindan oldukça farklı sonuçlara ulaşılmaktadır (Tabachnick ve Fidell, 2007). Geliştirilen ve farklı araştırmacıların kullanımına sunulan ölçeklerin yapı geçerliğini belirlemede kullanılan açımlayıcı faktör analizinin araştırmacılara göre değişen bulgularını ve esnekliğini ortadan kaldırmak için tekrar edilebilirlik analizlerinin yapılması önerilmektedir (Osborne ve Fitzpatrick, 2012). Doğrulayıcı faktör analizi için 20. yüzyılda başlayan tekrar edilebilirlik çalışmaları, açımlayıcı faktör analizi için 21. yüzyılda yapılmaya başlamış olsa da, günümüzde yaygın olarak kullanıldığından söz edebilmek mümkün değildir.

Tekrar edilebilirlik analizleri içsel (tek bir veri setini seçkisiz olarak ikiye ayırarak yapılan) ve dlşşal (ayrı ayrı toplanmış iki veri setine yapılan) olarak iki yolla gerçekleştirilebilir. Analiz sonucunda, farklı örneklemlerden aynı sayıda faktörün ortaya çıkması ve aynı maddelerin aynı faktörde yer alması (zayıf tekrar edilebilirlik) ile maddelere ilişkin faktör yükleri büyüklüklerinin aynı ranjda değişmesi (güçlü tekrar edilebilirlik) beklenmektedir. Özellikle yeni geliştirilen ve geniş kitlelerin kullanıma sunulan ölçekler için oldukça hayati bir analiz olan tekrar edilebilirlik analizleri ölçeğin geçerliğine ilişkin güçlü bir kanıt sunmaktadır (Floyd ve Widaman, 1995; Osborne ve Fitzpatrick, 2012).

$\mathrm{Bu}$ çalışma kapsamında bir içsel tekrar edilebilirlik analizi uygulaması gerçekleştirilmiştir. Her aşamasının ayrıntılı olarak tanıtıldığı düşünülen bu analizin hem gelecek çalışmalara örnek oluşturulması, hem de gerek ölçek geliştirenler, gerek bu ölçekleri kullanan araştırmacılar tarafından tanınması ve kullanımının yaygınlmştırılması amaçlanmıştır. Osborne ve Fitzpatrick (2012) tarafından aşamaları belirtilen bu analiz tüm ölçek geliştirme çalışmalarında rutin olarak yer almalı ve mümkün olduğu ölçüde yeni veriler toplanmak suretiyle dışsal geçerlik kanıtlarının da üretilmesine çalışılmalıdır. Böylelikle ölçeklerin ileri düzey geçerlik kanıtları ortaya konulmuş olacak ve yapılan ölçme ve değerlendirme işlemlerinin niteliği yükselecektir.

\section{KAYNAKÇA}

Briggs, S. R., \& Cheek, J. M. (1986). The role of factor analysis in the development and evaluation of personality scales. Journal of Personality, 54(1), 106-148.

Cohen, J., \& Cohen, P. (1983). Applied multiple regression/correlation analysis for the behavioral sciences. Hillsdale, NJ: L. NJ Eribaum. 
Comrey, A. L., \& Lee, H. B. (1992). A first course in factor analysis, (2nd Edition). Hillsdale, NJ: Lawrence Erlbaum Associates, Inc.

Costello, A., \& Osborne, J. (2005). Best practices in exploratory factor analysis: Four recommendations for getting the most from your analysis. Practical Assessment, Research And Evaluation, 10 (7), 1-9.

Çokluk, Ö., Şekercioğlu, G. \& Büyüköztürk, Ş. (2014). Sosyal bilimler için çok değişkenli istatistik: SPSS ve LISREL uygulamalarl, (3. Baskı). Pegem Akademi.

Deniz, K. Z., Saatçioğlu, Ö. \& Mor-Dirlik, E. (2014). Öz-belirleme ve çift etmen kuramına göre mesleki motivasyon ölçeği geliştirme çalışması. EJER CONGRESS 2014 Bildiri özetleri. 24-26 Nisan 2014 Istanbul Üniversitesi Kongre Merkezi. Anı Yayincilik.

Floyd, F.J. \& Widaman K. F. (1995) Factor analysis in the development and refinement of clinical assessment instruments. Psychological Asessment. 7(3). 286-299.

Goodwin, L. D. (1999). The role of factor analysis in the estimation of construct validity. Measurement in Physical Education and Exercise Science, 3(2), 85-100.

Hair, J. F. Jr. , Anderson, R. E., Tatham, R. L., \& Black, W. C. (1998). Multivariate data analysis, (5th Edition). Upper Saddle River, NJ: Prentice Hall.

Henson, R. K., \& Roberts, J. K. (2006). Use of exploratory factor analysis in published research common errors and some comment on improved practice. Educational and Psychological Measurement, 66(3), 393-416.

Kachigan, S. K. (1986). Statistical analysis: An interdisciplinary introduction to univariate \& multivariate methods. Radius Press.

Jöreskog, K. G., \& Sörbom, D. (1996). LISREL 8 user's reference guide. Uppsala, Sweden: Scientific Software International.

Osborne, J. W. (2008). Creating valid prediction equations in multiple regression: Shrinkage, Double Cross-Validation, and Confidence Intervals around prediction. J. w. Osborne (Ed.), Best practices in quantitative methods, 299-305.

Osborne, J. W., \& Fitzpatrick, D. C. (2012). Replication analysis in exploratory factor analysis: what it is and why it makes your analysis better. Practical Assessment, Research \& Evaluation, 17(15), 1-8.

Raykov, T., \& Marcoulides, G. A. (2008). Principal component analysis. An Introduction to Applied Multivariate Analysis. Lawrence Erlbaum Associates, Inc. Publishers. Routledge, EUA.

Stevens, J. (2002). Applied multivariate statistics for the social sciences. Mahwah, NJ: Lawrence Erlbaurn Associates.

Şahin-Kürşad, M. \& Nartgün, Z. (2015). Kayıp veri sorununun çözümünde kullanılan farklı yöntemlerin ölçeklerin geçerlik ve güvenirliği bağlamında karșılaștırılması. Eğitimde ve Psikolojide Ölçme ve Değerlendirme Dergisi. 6(2), 254-267.

Tabachnick, B. G. \& Fidell, L. S. (2007). Using multivariate statistics. Boston: Pearson/Allyn \& Bacon.

Thompson, B. (1999). Five Methodology Errors in Educational Research: The Pantheon of Statistical Significance and Other Faux Pas. In B. Thompson (Ed.), Advances in Social Science Methodology (Vol. 5, pp. 23-86). Stamford, CT:JAI Press.

Thorndike, R. M. (1997). Measurement and evaluation in psychology and education (6th ed). Upper Saddle River, NJ: Merrill/Prentice Hall. 


\section{EXTENDED ABSTRACT}

\section{Introduction}

Factor analysis has been the most frequently used technique since the day of its invention. In many research, it has been used in order to explore and confirm the psychological structure of the scale which has been explored earlier. In spite of the prevalent usage of this technique, there are so many misapplications in research for this analysis. Especially for the exploratory factor analysis, in many points, the researchers have to choose from the options, so it is very common to get different factor solutions from the same data sets. Because of the difference in the results, the validity and the reliability of the results become questionable. To get more valid and reliable solutions and make the results acceptable for the population, extra studies are needed and one of them is the replicability of the analysis. In the replication analysis, the validity of the factor solution is analysed by doing the same analysis on two different group and the similarities of the results are analysed. It can be done in two ways, either the data are divided into two groups randomly, or a new data are gathered from the similar but another group. The explanatory factor analyses are administered to these groups, and firstly the factor structures, after the items and their loadings are compared. If the factor solutions are determined correctly, so similar results are expected to get. The similarities of the results are compared by calculating the differences between the factor loadings variations in different data sets.

\section{Method}

In this study, it was aimed at giving information about the replication of explanatory factor analysis and doing an example for the replication study. In this study, there was no objective to test theory or compare the groups or some traits of the people. For this reason, this study is a fundamental research. In order to make a replication analysis, data gathered from the development stage of the Vocational Motivation was used. The data composed of 469 university students' responses were used and this data file was divided into two groups randomly. For each of the group, explanatory factor analysis was administered and the results were analysed.

\section{Findings, Discussion and Results}

After seperating the data set into two random data sets, explanatory factor analysis was administered for two and three dimensions on both the new data sets and original one. Generally, two dimensional factor solution was found unacceptable for this scale, because the scale was developed regarding three dimensions. So the analysis were repeated for three dimensions. For the three dimensional analysis, the original factor structure of the scale was obtained. It was found that the scale was composed of three dimensions and the factor loadings were higher than the limit value 0,32. After analysing the results of the original data set, the results from the different data sets were compared. Firstly, it was found that the same factor structure was obtained from the each data sets and it means that three dimensional structures was valid for each data sets and the basic replicability was accepted for this scale. After the structure, the items were analysed and it was found that all items were grouped under their original dimensions. Lastly, the differences between the factor loadings were calculated and the differences were found at negligible level. As a result, it were found that the strong replicability of this scale was achieved. 